\title{
Metabolomics of fecal samples: a practical consideration
}

Article

Accepted Version

Creative Commons: Attribution-Noncommercial-No Derivative Works 4.0

Matysik, S., Le Roy, C. I., Liebisch, G. and Claus, S. P. (2016) Metabolomics of fecal samples: a practical consideration. Trends in Food Science and Technology, 57. pp. 244-255. ISSN 0924-2244 doi: https://doi.org/10.1016/j.tifs.2016.05.011 Available at https://centaur.reading.ac.uk/65839/

It is advisable to refer to the publisher's version if you intend to cite from the work. See Guidance on citing.

To link to this article DOI: http://dx.doi.org/10.1016/j.tifs.2016.05.011

Publisher: Elsevier

All outputs in CentAUR are protected by Intellectual Property Rights law, including copyright law. Copyright and IPR is retained by the creators or other copyright holders. Terms and conditions for use of this material are defined in the End User Agreement.

\section{www.reading.ac.uk/centaur}

\section{CentAUR}

Central Archive at the University of Reading

Reading's research outputs online 


\section{Accepted Manuscript}

Metabolomics of fecal samples: a practical consideration

Silke Matysik, Caroline Ivanne Le Roy, Gerhard Liebisch, Dr Sandrine Paule Claus

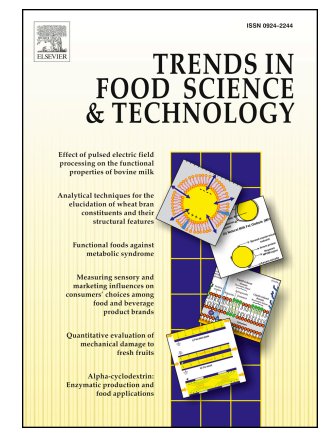

PII: S0924-2244(16)30198-4

DOI: $\quad$ 10.1016/j.tifs.2016.05.011

Reference: TIFS 1813

To appear in: Trends in Food Science \& Technology

Received Date: 29 August 2015

Revised Date: 6 April 2016

Accepted Date: 16 May 2016

Please cite this article as: Matysik, S., Le Roy, C.I., Liebisch, G., Claus, S.P., Metabolomics of fecal samples: a practical consideration, Trends in Food Science \& Technology (2016), doi: 10.1016/ j.tifs.2016.05.011.

This is a PDF file of an unedited manuscript that has been accepted for publication. As a service to our customers we are providing this early version of the manuscript. The manuscript will undergo copyediting, typesetting, and review of the resulting proof before it is published in its final form. Please note that during the production process errors may be discovered which could affect the content, and all legal disclaimers that apply to the journal pertain. 


\section{ACCEPTED MANUSCRIPT}

\section{Metabolomics of fecal samples: a practical consideration}

2

3 Silke Matysik ${ }^{1}$, Caroline Ivanne Le Roy ${ }^{2}$, Gerhard Liebisch ${ }^{1}$, Sandrine Paule

4 Claus $^{2^{*}}$

5

61 Institute of Clinical Chemistry and Laboratory Medicine, University of

7 Regensburg, Germany.

82 Department of Food and Nutritional Sciences, The University of Reading,

9 Whiteknights campus, PO Box 226, Reading RG6 6AP, UK.

10

$11 *$ Corresponding author:

12 Dr Sandrine Claus, s.p.claus@reading.ac.uk, +44 (0) 1183788717

13

14 Key words: Metabolomics, Lipidomics, Feces, Methods

15

16 

analyse fecal material is urgently needed.

\section{ABSTRACT}

\section{Background} hyperbolome.

\section{Scope and Approach}

\section{Key Findings and Conclusions}

Metabolic profiling is becoming increasingly popular to identify subtle metabolic variations induced by diet alterations and to characterize the metabolic impact of variations of the gut microbiota. In this context, fecal samples, that contain unabsorbed metabolites, offer a direct access to the outcome of diet - gut microbiota metabolic interactions. Hence, they are a useful addition to measure the ensemble of endogenous and microbial metabolites, also referred to as the

Many reviews have focused on the metabolomics analysis of urine, plasma and tissue biopsies; yet the analysis of fecal samples presents some challenges that have received little attention. We propose here a short review of current practices and some practical considerations when analyzing fecal material using metabolic profiling of small polar molecules and lipidomics.

To allow for a complete coverage of the fecal metabolome, it is recommended to use a combination of analytical techniques that will measure both hydrophilic and hydrophobic metabolites. A clear set of guidelines to collect, prepare and 


\section{Highlights}

40 1. Untargeted metabolic profiling of fecal material is robustly achieved using NMR-based metabolomics

2. Mass spectrometry is mostly used for targeted metabolic profiling of a class of molecules for deep coverage and high sensitivity

3. Lipidomics profiles are extremely complex as they contain a mixture of endogenous, diet-related and microbial lipids that may be of interest for bacterial identification 


\section{INTRODUCTION}

49 The gut microbiota is a highly metabolically active community of micro-

50 organisms inhabiting all niches along the intestine, that is now recognized as a

51 critical regulator of its host homeostasis.(O'Hara \& Shanahan, 2006) It has been

52 estimated that the gut microbiota as a whole contains 100 times more genes

53 than human cells, hence its potential to be a key metabolic player. It is therefore

54 expected that modifying the gut microbial balance would induce a shift in the gut

55 metabolic environment that can in turn affect our own metabolism.

56 The gut microbiota composition varies considerably over a lifetime.(Yatsunenko

57 et al., 2012) It takes approximately two years to a newborn to acquire a stable

58 GM population(Palmer, Bik, DiGiulio, \& Relman, 2007) that will evolve through

59 life under the pressure of various factors such as, for instance, diet, lifestyle and

60 exposure to antibiotics, all commonly referred to as the 'exposome'. (Claesson et

61 al., 2011; Claus \& Swann, 2013; Lozupone, Stombaugh, Gordon, \& Jansson, 2012)

62 Later in life, a loss of microbial diversity is generally observed with senescence.

63 (Biagi, Candela, Fairweather-Tait, Franceschi, \& Brigidi, 2011; Claesson et al.,

64 2011) As recently demonstrated, even perturbations of the circadian cycle have

65 been observed to affect the balance of the gut microbial community. (Mukherji,

66 Kobiita, Ye, \& Chambon, 2013; Voigt et al., 2014)

67 Diet is the main factor influencing gut microbiota composition since it provides

68 microorganisms with their main organic carbon source.(Flint, Duncan, Scott, \&

69 Louis, 2015) This connection was recently further evidenced by a study

70 demonstrating that a drastic change of diet such as switching from vegetarian to

71 carnivorous and inversely can profoundly reorient the GM ecosystem in a very

72 short period of time.(David et al., 2015) Thus, along genetic and other 
73 environmental factors, diet strongly contributes to the unique character of every

74 individual's gut microbiota.

75 Bacteria have a high metabolic activity that generates a wide range of products

76 such as organic acids, alcohols and gas that may become available for the host or

77 other commensal bacteria for cross-feeding. This symbiotic activity shapes the

78 gut metabolic environment. Complex carbohydrates, that cannot be digested in

79 the upper gastrointestinal track and are a major source of carbon for colonic

80 bacteria.(Scott, Duncan, \& Flint, 2008) Their fermentation results in the

81 production of short chain fatty acids (SCFAs: acetate, propionate, butyrate and

82 valerate) that play an important role in human health.(Besten, van Eunen, Groen,

83 \& Venema, 2013) Other food components such as lipids and proteins can largely

84 impact the composition of the gut microbiota and its metabolic

85 activity.(Sonnenburg \& Sonnenburg, 2014) Endogenous secretions such as the

86 bile acids contained in bile are important regulators of the gut microbiota.

87 Reciprocally, gut bacteria are known to extensively alter the structure of sterols

88 that leads to the formation of secondary and tertiary bile acids.(Sayin et al.,

89 2013) This is an example of a major gut microbiota-host interplay that

90 contributes to regulating the absorption of dietary lipids during digestion. Hence,

91 the diet-gut microbiota interaction plays a key role in the metabolic homeostasis

92 of its host. It is therefore of utmost importance to understand the biological

93 mechanisms that underlie this complex relationship. Systems biology

94 approaches that study a system as a whole (e.g. a micro-organism within a host,

95 the interactions occurring within a community of bacteria etc.) are increasingly

96 popular to decipher these interactions. In particular, metabolic profiling

97 techniques are tremendously useful to understand the metabolic pathways 
98 regulated through the host-gut microbiota interaction. A variety of sample types

99 ranging from biofluids to tissue biopsies can be analyzed to capture the systemic

100 metabolic response to the exposome. Of particular interest, feces are easily

101 accessible and provide a non-invasive window to study the outcome of the diet-

102 gut microbiota-host interaction through the analysis of remaining unabsorbed

103 metabolites. Yet, the analysis of fecal samples for metabolic profiling has

104 received little attention. In this review, we will explore the dominant

105 technologies that are commonly applied to assess the fecal metabolome and

106 discuss about practical aspects that must be considered when dealing with this 107 material.

109 NMR-based metabolomics of fecal samples

110 Metabolic profiling, also referred to as metabolomics, is mostly achieved using

111 two analytical platforms: nuclear magnetic resonance (NMR) spectroscopy and 112 mass spectrometry (MS) to evaluate the metabolic composition of a chosen

113 biological matrix. These techniques allow the simultaneous measurement of a

114 wide range of metabolites in a sample, and when combined, offer a large 115 coverage of the metabolome (i.e. the set of metabolites in a sample).

116 Untargeted metabolic profiling by ${ }^{1} \mathrm{H}$ NMR spectroscopy measures all

117 metabolites with nonexchangeable protons that are present in a sample in a

118 relatively high concentration (in the micromolar range). Because it is highly

119 reproducible, is cost effective and usually requires only a few simple preparation 120 steps, NMR-based metabolic profiling has been widely applied to the analysis of 121 virtually all biological matrices, including feces. (Li et al., 2011; Martin et al., 122 2010; Saric et al., 2008) 
123 In humans, ${ }^{1} \mathrm{H}$ NMR-based metabolic profiling of fecal material has been

124 successfully applied to assess the impact of the composition of the gut

125 microbiota on the gut metabolic environment in the context of ulcerative colitis

126 (UC) and irritable bowel syndrome (IBS).(Le Gall et al., 2011) A similar approach

127 was applied to monitor the gut microbial metabolic activity in elderly (Claesson

128 et al., 2012). In this study, it was possible to cluster patients according to their

129 community setting (length of hospital care) based on fecal water profiling. A

130 recent study also demonstrated the possibility of evaluating independent

131 bacterial contributions at a species level to the gut metabolic environment using

132 this technique. (Le Roy et al., 2015). Applied to the monitoring of probiotic

133 consumption, it was possible to detect faecal metabolic modifications in

134 response to increased Bifidobacterium in the colon (Ndagijimana et al., 2009)

135 In animal models, profound reorientation of the gut microbial community

136 induced by antibiotics in mice was associated to modifications of fecal metabolic

137 profiles measured by the same technique. This was mainly associated to a

138 modification in the fecal content in amino acids and SCFAs.(Yap et al., 2008).

139 Similarly, Romick-Rosendale et al., (Romick-Rosendale et al., 2009) also showed

140 a modification of murine fecal metabolic profiles in response to antibiotic

141 treatments. NMR-based metabonomics analysis of fecal water also proved to be

142 able to differentiate age groups in mice. (Calvani et al., 2014) Finally NMR-based

143 metabonomics can be applied to nutrition (also referred to as

144 nutrimetabonomics) (Claus \& Swann, 2013) to access modification of the gut

145 metabolic environment in response to diet modulation. As an example, a study

146 by De Filippis et al., (De Filippis et al., 2015) used NMR-based metabonomics to

147 evaluate the impact of a Mediterranean diet on gut microbiota metabolic activity. 
148 The study demonstrated that following a Mediterranean diet improved the

149 detection of SCFAs in fecal waters compared with a western diet. Similarly, fecal

150 metabolic modifications have been observed in response to food

151 supplementation investigated in in vitro gut models. (Frost et al., 2014).

152 Since fecal samples contain a complex mixture of metabolites, most NMR-based

153 metabolic profiling studies use a selective NOESY experiment with water

154 presaturation applied during recycle delay and mixing time to detect signals

155 caused by small molecular weight molecules as well as some lipids. This is often

156 referred to as the NOESYPR1D experiment [RD-90- $\left.\mathrm{t}_{1}-90^{\circ}-\mathrm{t}_{\mathrm{M}}-90^{\circ}-\mathrm{ACQ}\right]$, where

$157 \mathrm{RD}$ is the recycle delay, $\mathrm{t}_{1}$ a short interval of about $3 \mu \mathrm{s}, \mathrm{t}_{\mathrm{M}}$ the mixing time of

158 approximately $100 \mathrm{~ms}$ and ACQ the FID acquisition period. Interestingly, a

159 number of studies investigating fecal samples have also used a CPMG (Carr-

160 Purcell-Meiboom-Gill) experiment, (Bjerrum et al., 2014; Li et al., 2011) which

161 uses $t_{2}$ filtering to reduce signal resonance from large macromolecules.

162 (Meiboom \& Gill, 1958) However, this should be considered with care since the

163 number of loops and length of echo time that must be optimized for each CPMG

164 experiment would determine the signal/noise ratio, therefore preventing

165 absolute quantification. This is not an issue when only relative quantifications

166 are needed.

167 Preparation of fecal material for metabolomics studies

169 Recently, Deda et al. reviewed sample preparation methods for fecal samples for

170 metabolomic analysis.(Deda, Gika, Wilson, \& Theodoridis, 2015) They provided a

171 comprehensive overview of fecal sample preparation for NMR, GC-MS and LC-MS

172 analysis including some critical aspects and specific requirement of the different

173 technologies. Therefore, we will not cover sample preparation in details here but 
174 a summary of the protocols and methods used in previously published research

175 papers are presented in Table 1 . However, it is noteworthy that this review

176 highlighted the lack of consensus about sample preparation for both metabolic

177 profiling technologies. For sample extraction, it seems that a dilution of 1 volume

178 of feces material for 2 volumes of PBS buffer is most commonly used. The buffer

179 is generally composed of a mixture of $\mathrm{H}_{2} \mathrm{O}$ and $\mathrm{D}_{2} \mathrm{O}$ (minimum $10 \%$ ) in various

180 amounts, with an adjusted $\mathrm{pH}$ of 7.4 and an internal standard to serve as NMR

181 reference. The most common internal reference is 3-(trimethylsilyl)-2,2,3,3-

182 propionate-d4 (TSP). Deda et al. discuss that TSP signal intensity can be affected

183 by $\mathrm{pH}$ but so far, the only alternative is 2,2-dimethyl-2-silapentane-5-sulfo- nate-

184 d6 (DSS). However, unlike TSP, DSS has multiple small resonances in addition to

185 the main resonance at $0 \mathrm{ppm}$ that may interfere with other signals and therefore

186 it should be used at a very low concentration $(0.01 \%$ would be recommended).

187 Homogenization of fecal material can be done directly in the NMR buffer that will

188 be used for NMR analysis, minimizing the number of sample processing steps

189 that may alter metabolic profiling. However, it also appears that a

190 water/methanol extraction tends to improve the overall recovery of fecal

191 metabolites. Nevertheless it was also argued in a publication by Jacobs et al.,

192 (Jacobs et al., 2007) that methanol extracts were less representative of the real

193 metabolic composition of the fecal water encounter in the colon and therefore of

194 the metabolite pool that interacts with the intestinal membrane.

196 Mass spectrometry-based metabolomics of fecal samples

197 Untargeted metabolic profiling using MS-based techniques is more sensitive than

198 NMR (in the nanomolar range) but often generates a large amount of unknown

199 signals and as a consequence, these techniques have been mostly used for 
targeted metabolomics, where the method is optimized to the detection of a

201 specific class of samples. MS-based metabolic profiling is usually achieved using

202 either gas chromatography (GC-MS) or liquid chromatography (LC-MS).

203

204

GC-MS based metabolomics

205 The group of Sébédio presented two GC-MS methods to analyze the metabolome 206 of fecal water. In their first study they used an ethyl chloroformate derivatization

207 (Gao et al., 2009). In fecal water samples of healthy subjects 73 compounds were 208 identified and thereof 34 validated by reference standards. The second study 209 applied trimethylsilylation and identified 133 compounds (including amino 210 acids, carbohydrates short and long chain fatty acids and phenolics) in human

211 fecal water and the majority validated by authentic standards (Gao, Pujos212 Guillot, \& Sébédio, 2010). In both studies several extraction conditions were 213 tested and the highest recovery of metabolites detected for neutral and basic $\mathrm{pH}$ 214 which was confirmed also by others (Deda et al., 2015). However, it has been 215 suggested that increasing $\mathrm{pH}$ from 6 to 7 may decrease the loss of volatile SCFA 216 during lyophilization (Gao, Pujos-Guillot, \& Sébédio, 2010).

217 Phua et al. presented a GC-TOF-MS analysis of feces after freeze drying followed 218 by oximation and silylation (Phua, Koh, Cheah, Ho, \& Chan, 2013). The authors 219 argue that removal of a variable content of water increased the reproducibility of 220 sample preparation. They identified 107 metabolites by matching with different 221 mass spectra libraries. However, only a few analytes were confirmed by 222 reference substances. This method was applied in detection of colorectal cancer 223 (Phua et al., 2014). Main markers for CRC differentiation include decreased level 224 of fructose, nicotinic acid and linoleic acid in CRC patients. 
225 Using a similar methodology, Weir et al. analyzed the fecal metabolome in CRC

226 patients (Weir et al., 2013). Metabolite identification was based on database

227 matching. In agreement with Phua et al. they detected decreased linoleic acid in

228 CRC patients compared to healthy controls. Moreover, reduced level of oleic and

229 elaidic acids were found in CRC patients. In contrast to these fatty acids (FAs)

230 myristic acid and several amino acids were increased in CRC patients. It is

231 noteworthy that fatty acid identification does not differentiate double bond 232 positions.

233 A very efficient approach to analyze volatile organic compounds (VOC) of feces is 234 headspace solid-phase microextraction (SPME). Volatile metabolites are 235 adsorbed to polymer coated fibers which are analyzed by GC-MS. Typically the 236 analyte spectrum includes hydrocarbons, alcohols, aldehydes and organic acids 237 (primarily short chain) and their esters. Dixon et al. tested different fibers to get 238 a comprehensive coverage of VOCs (Dixon et al., 2011). Ahmed et al investigated 239 fecal VOCs in patients with irritable bowel syndrome, active Crohn's disease, 240 ulcerative colitis and healthy controls (Ahmed, Greenwood, de Lacy Costello, 241 Ratcliffe, \& Probert, 2013). They identified 240 metabolites which allowed a 242 differentiation of patients with irritable bowel syndrome from patients with 243 inflammatory bowel diseases and healthy controls.

\section{LC-MS based metabolomics}

246 In contrast to GC-based methods, LC-MS usually does not require metabolite 247 derivatization but is restricted to analytes containing polar groups. Cao et al. 248 used UPLC-MS/TOF-MS to analyze the fecal metabolome in patients with liver

249 cirrhosis and hepatocellular carcinoma (HCC) (Cao et al., 2011). Fecal samples 250 were homogenized, centrifuged and injected after filtration. Metabolic features 
251 were analyzed by multivariate data analysis. Chenodeoxycholic acid, 7-

252 ketolithocholic acid, urobilinogen, urobilin, lysophosphatidylcholine (LPC) 16:0

253 and 18:0 were found to discriminate between healthy controls and patients with

254 liver cirrhosis and HCC. Whereas LPC species were found in increased levels, the

255 other discriminatory markers were decreased in the patient samples. The

256 identities of these markers were confirmed by comparison of chromatographic

257 retention and product ion spectra with authentic standards.

258 A study by Jimenez-Girón investigated changes in the fecal metabolome related

259 to the consumption of red wine (Jiménez-Girón et al., 2015). Feces samples were

260 analyzed after mixing with saline solution, centrifugation and filtration by

261 UHPLC-TOF-MS. Mass features were subjected to statistical analysis and 37

262 metabolites were found to be related to wine intake. Metabolite identification

263 was performed by database searching and confirmation by authentic standards.

264 This way 14 metabolites could be identified tentatively, 6 mass features match to

265 standards $(\mathrm{m} / \mathrm{z}$ and retention time).

266 The fecal metabolome of rats with chronic renal failure were analyzed by Zhao et

267 al. (Zhao, Cheng, Wei, Bai, \& Lin, 2012). Homogenized fecal samples were

268 extracted with acetonitrile and analyzed by UPLC-Q-TOF-MS. Both polarities

269 including fragment ions were recorded and used for identification and validation

270 of mass features. Except an increase of adenine (used to induce kidney failure), 8

271 lipid metabolites were found decreased in rats with chronic renal failure.

272 An interesting approach to profile amine- and phenol-containing metabolites 273 was presented recently by $\mathrm{Su}$ and colleagues (Su et al., 2015). Dried fecal 274 samples are extracted sequentially with water and acetonitrile followed by 275 derivatization with dansyl chloride. As an internal standard an aliquot of a 
276

277

278

279

280

281

282

283

284

285

286

287

288

289

290

291

292

293

294

pooled fecal extract was added which was derivatized with ${ }^{13} \mathrm{C}$-labelled dansyl chloride. Dansylation improves both LC separation efficiency and MS response of the compounds. 6200 peaks were detected in 237 different samples and 67 metabolites (mainly amino acids) were identified based on mass and retention time matching to a dansyl standard library.

In summary, both GC- and LC-based metabolomics studies are able to discover a number of differentially regulated metabolic features in fecal samples in various studies. However frequently, only a few of these features could be identified. Moreover, several studies did not prove the identity by authentic standards but only by matching of $m / z$ values to database entries. In general, GC-MS based studies identify an increased number of metabolites which may partly reflect the superior chromatographic resolution and peak shape of GC compared to LC methods. This allows a more reliable extraction and comparison of metabolic features between different samples. Additionally, GC usually provides mass spectra generated by ionization-induced fragmentation that are useful for metabolite identification. A disadvantage of GC analyses is a more laborious sample preparation including the need of derivatization as a potential source of artifacts. Conversely, GC-MS clearly shows advantages compared to LC-MS in terms of deleterious matrix effects. So it is generally accepted that quantification of analytes by LC-MS requires internal standards, ideally stable isotope labeled for each analyte. Therefore a major source of errors of LC-MS metabolic profiling may be related to undiscovered matrix effects especially in heterogeneous sample material like feces. Consequently, in order to provide solid data metabolomics studies should validate their biomarkers by quantitative analysis 
using authentic standards and internal standards especially when LC-MS is

301 applied at least in a representative cohort.

302

303

\section{Mass spectrometry-based targeted metabolic analysis}

304 In contrast to untargeted analysis, targeted analysis is confined to a limited set of

305 analytes. These methods are optimized for high analyte recoveries during 306 sample preparation and a reproducible, accurate quantification of the target 307 molecules. Most methods rely on internal standards (mandatory for LC-MS), 308 calibration lines and method validation shows their performance.

311 An excellent example for targeted analysis of potential biomarkers is the 312 quantitation of short chain fatty acids (SCFA). A recent study by Han et al. 313 presented a LC-MS/MS method for SCFA quantification in human feces (Han, Lin, 314 Sequeira, \& Borchers, 2014). SFCAs are converted to 3-nitrophenylhydrozones 315 (3NHPH) which are separated by reversed phase chromatography and detected 316 in negative ion mode. The method covers 10 straight- and branched chain SCFAs.

317 In an elegant way, this study introduced an internal standard for every analyte 318 by conversion of a standard mixture with a ${ }^{13} \mathrm{C}_{6}$-labeled derivatization reagent. 319 This method showed a high reproducibility and analysis of human fecal samples 320 revealed an increased fraction of branched-chain SCFA in T2D patient compared 321 the other analyzed samples.

322 In contrast to LC-MS/MS analysis, GC-MS may rely on a fewer number of internal 323 standards since matrix effects are less pronounced. A study by Zheng et al. 324 quantified SCFAs and branched-chain amino acids (BCAAs) in feces and other 325 biological materials using $\mathrm{D}_{3}$-caproic acid as internal standard (Zheng et al., 326 2013) after propyl chloroformate derivatization. 
Sterols and bile acids belong to another class of analytes studied for a long time

330 in feces by targeted analysis. Cholesterol is an essential component of all

331 mammalian cell membranes and it is the precursor of steroid hormones and bile

332 acids. There has been a long interest in the intestinal metabolism of cholesterol

333 because the gut microbiome is highly involved in the balance between

334 absorption, excretion and metabolism. Between $34-57 \%$ of dietary cholesterol is

335 absorbed from the human intestine (Grundy et al., 1977). Fecal excretion of total

336 neutral sterols has been reported to range between 350-900 mg/day, of which

$33720 \%$ is cholesterol. There are several primary sources of fecal cholesterol:

338 unabsorbed from the diet, bile and intestinal epithelium. It is well-known that

339 the luminal cholesterol can be metabolized by the gut microbiota. This

340 cholesterol escaping intestinal absorption is degraded to coprostanol through

341 reduction of the double bond at C-5. (Figure 1) Coprostanone is also produced in

342 a lesser extent. (Eyssen et al., 1974; Lichtenstein, 1990; Gerard, 2013). In human

343 feces, cholesterol derivatives have been reported in the following proportions:

344 coprostanol 65\%, cholesterol 20\%, coprostanone $10 \%$. (Figure 1) Other minor

345 derivatives include cholestanone, cholestanol and epicoprostanol.

346 Many attempts have been made to isolate bacteria capable of reducing

347 cholesterol to coprostanol from human and animal faeces (Snog-Kjaer et al.,

348 1956; Crowther et al., 1973). Certain anaerobic bacteria from human faeces are

349 known to hydrogenate cholesterol in vitro. Cholesterol reduction by common

350 intestinal bacteria such as Bifidobacterium, Clostridium, and Bacteriodes has

351 also been reported and reviewed extensively (Gerard, 2013). In addition,

352 reference values have been generated for fecal excretion of cholesterol and 
353 coprostanol (Benno et al., 2005) to differentiate between high-, low- and non-

354 converters.

355 Bile acids are derived from cholesterol and are produced by every class of

356 vertebrate animals and show substantial diversity across species (Hofmann et 357 al., 2010). In bile, bile acids rapidly form mixed micelles with secreted 358 cholesterol and phospholipids. Bile acids enter the intestine as di- and 359 trihydroxylated acyl conjugates, in mammals with the amino acids taurine and 360 glycine (Hofmann, 2009). In the intestinal lumen, conjugated bile acids directly 361 affect the microbiota because they exert antimicrobial properties besides 362 stimulating enterocytes to secrete undefined antimicrobial compounds 363 (Hofmann et al., 2006). Conversely, gut bacteria structurally alter bile acids 364 through deconjugation of taurine, glycine and sulfate moieties and hydroxylation 365 of the sterol backbone.

366 During digestion, bile acids facilitate lipid absorption by stabilizing lipid micelles.

367 Since bile acids have various degrees of hydrophobicity, and therefore various 368 stabilizing properties, the bile acid composition of the bile is an important factor 369 that regulates fat absorption. The enterohepatic cycle of bile acids is a key 370 regulator of hepatic bile acid de novo synthesis and cholesterol excretion. Indeed, 371 bile acids undergo extensive reabsorption by active and passive routes so that $37295 \%$ of secreted bile acids are reabsorbed daily. Since deconjugated bile acids 373 are less polar, passive diffusion is reduced and it has been shown that active 374 deconjugation by gut bacteria increases the overall excretion of bile acids in 375 feces, hence the role of bacteria in regulating fecal cholesterol loss (Claus et al., 376 2011; 2008; Kellogg, Knight, \& Wostmann, 1970; Sayin et al., 2013). In human, a 377 limited number of commensal bacteria are capable of removing the 7-hydroxyl 
378 group from di- and trihydroxy bile acids and 7-deoxy species are formed. The

379 most common 7-deoxy bile acids are lithocholic and deoxycholic acid. Many

380 excellent reviews exist in the recent literature covering bile acid function,

381 signaling and therapeutic potential (Ridlon et al., 2006; Hofmann et al., 2008;

382 2009; Trauner et al., 2010; Hagey et al., 2013).

383

384

385

386

387

388

389

390

391

392

393

394

395

396

397

398

399

400

401

402

403

Sample Preparation and Instrumental Strategies for Targeted Metabolomics Analysis

SCFAs are volatile and therefore freeze drying of stool samples may result in lower recovery. Han et al. used homogenized samples and extracted SCFAs by addition of $50 \%$ aqueous acetonitrile (Han, Lin, Sequeira, \& Borchers, 2014). These extracts were subjected directly to derivatization with 3nitrophenylhydrazine $\mathrm{HCl}$. Zheng et al. used $0.005 \mathrm{M}$ aqueous $\mathrm{NaOH}$ to homogenize fecal samples at $4^{\circ} \mathrm{C}$ to protect the volatile SCFAs (Zheng et al., 2013). The homogenates were derivatized with propyl chloroformate and extracted with hexane extraction for GC-MS analysis.

Extensive overviews of state-of-the-art methods to analyze fecal steroids can be found in the literature, e.g. (Story \& Furumoto, 1991; Perwaiz et al., 2002; Griffiths \& Sjövall, 2010). The first and often referred methods for fecal steroid and bile acid analysis were a combination of thin-layer chromatography and gasliquid chromatography published 1965 by Grundy, Miettinen and co-workers (Grundy et al., 1965; Miettinen et al., 1965). Sample pretreatment included homogenization, saponification and liquid/liquid extraction followed by thinlayer chromatography and trimethylsilylation. Individual components are then quantitatively measured by gas-liquid chromatography equipped with a flame ionization detector. Bile acids underwent a methylation step before thin-layer 
404 chromatography. This approach was applied in many studies for the analysis of

405 endogeneous and exogeneous (labelled) compounds.(Spritz et al., 1965; Grundy 406 et al., 1969). Evrard and Janssen suggested a method for bile acid analysis which 407 took advantage of a different extraction scheme and an alternate derivatization 408 (Evrard \& Janssen, 1968). The method is based on heating in presence of acetic 409 acid and extraction with toluene. Quantification was done as methylketone 410 derivatives. In the 1980s methods with subfraction steps have been proposed to 411 isolate taurine and glycine conjugated and sulphated bile acids (Setchell et al., 412 1983; Owen et al., 1984) using GC analysis. Nowadays, the most common 413 strategies to analyze sterol profiles including cholesterol, coprostanol and 414 coprostanone in faeces are based on GC-MS. The sample preparation protocol 415 includes repeated sampling for better representativeness, a dilution step, 416 hydrolyzation of esterified sterols, extraction with a mixture of hexane and 417 ethanol and derivatization (Lutjohann et al., 1993; Midtvedt et al., 1990; Andrasi 418 et al., 2011). For example, Korpela et al. suggested a very detailed protocol which 419 included a $72 \mathrm{~h}$ sampling of faeces, methanol-chloroform extraction, separation 420 of free and esterified sterols with a Lipidex-5000 column, saponification, 421 separation of hydroxylated and oxo-forms by a second column, and trimethylsilyl 422 derivatization followed by GCMS (Korpela, 1982). LC-MS and MS/MS have also 423 been widely exploited for bile acid analysis of human urine, plasma/serum, bile 424 and also feces (Perwaiz et al., 2002; Hagio et al., 2009; Griffiths \& Sjövall, 2010). 425 Quantification is best performed by addition of isotope labeled internal 426 standards. These should be added as early as possible in the analytical process so 427 as to account for analyte loss during sample preparation. 
Bile acids can usually be extracted from fluids and tissues with ethanol, methanol

429 or acetonitrile. An ethanol fraction may be followed by extraction with a less

430 polar solvent, such as chloroform, to recover less polar bile acid derivatives (e.g.,

431 the fatty acid esters) and bile acids remaining in the lipophilic residue (Griffiths

432 et al., 2010). Batta et al. compared different methods to extract fecal bile acids

433 and sterols (Batta et al., 1999) to suggest a simplified method of extraction.

434 However, this is based on the assumption that fecal bile acids are unconjugated

435 (Setchell et al., 1983), which is not a valid assumption for many clinical 436 conditions, especially when subjects have been exposed to oral antibiotic 437 treatments that have affected the gut microbial ecosystem.

438 Lipidomics

440 Parallel to metabolomics, lipidomics emerged during the past decade as a 441 specialized discipline. Today virtually a full quantitative coverage of the lipidome 442 is possible by mass spectrometric methods (Wenk, 2010).

443 In contrast to global metabolomics, lipidomic analysis mostly relies on lipid

444 extracts prepared by extraction with apolar solvents like chloroform (Bligh \& 445 Dyer, 1959) or MTBE (Matyash, et al., 2008). The complexity of these extracts is 446 greatly reduced compared to protein precipitates frequently applied for 447 untargeted metabolomics as polar analytes are removed.

448 Up to now there are only a few studies of the fecal lipidome. Gregory et al. 449 compared different extraction methods for lipidomics profiling by LC-HR-MS 450 (high resolution MS) (Gregory et al., 2013). Stools of preterm infants were 451 homogenized in water and lipophilic metabolites were extracted using either 452 dichloromethane or a MTBE/hexafluoroisopropanol mixture. Additionally, the 453 effect of pressure cycling on the extraction of lipid species was investigated. 
454 Polar species like lyso-lipids showed a higher response after MTBE extraction

455 whereas increased responses were observed after dichloromethane extraction

456 for more hydrophobic species. The effect of pressure cycling does not show a

457 consistent increase of the lipid species response for both extraction methods.

458 Analysis by reversed phase chromatography couple to HR-MS was performed in

459 both positive and negative ion modes. 304 lipid species were identified by

460 unique monoisotopic $\mathrm{m} / \mathrm{z}$ and retention time including 29

461 phosphatidylethanolamine (PE), 22 phosphatidylcholine $(\mathrm{PC}), \quad 14$

462 phosphatidylglycerol (PG), 88 triacylglycerol, 19 diacylglycerol and interestingly

46350 ceramide species.

464 Recently, Davis and colleagues analyzed stools from mice fed a high fat or control

465 diet with or without induction of colitis-associated tumors (Davies et al., 2014).

466 Feces was homogenized by repeated freeze-thawing, minced to powder and

467 extracted with a modified Bligh and Dyer method. Samples were quantified by

468 shotgun lipidomics. However, mass spectra displayed very low intensities. The

469 selection of dioleoyl species of PE, PS, PI as internal standards has to be

470 considered as a potential source of error for quantification since these species

471 may be present in feces (PE and PI 36:2 were detected by Gregory et al. (Gregory

472 et al., 2013)). A general problem of this study and also a number of metabolomics

473 studies is the annotation of lipid species. Davis et al. showed detailed

474 annotations including even double bond positions of the fatty acyls. Such

475 structural differences usually may not be resolved by standard lipidomic or

476 metabolomics methods. Most methods determine the number of carbons and

477 number of double bonds with the acyl chains. Therefore, it is recommended to

478 annotate only structural details which are resolved by the analysis (Liebisch et 
al., 2013). Moreover, common shorthand nomenclature provides a standard for reporting and searching of lipid species including deposition in and retrieval from databases.

Figure 2 presents the result of a lipidomic analysis of a fecal sample using a method that has been applied to a variety of sample types such as plasma (Sigruener et al., 2014), lipoproteins (Scherer, Böttcher, \& Liebisch, 2011), cells (Leidl, Liebisch, Richter, \& Schmitz, 2008), cell culture (Binder, Liebisch, Langmann, \& Schmitz, 2006) and tissues (Hebel et al., 2015). Fecal samples were homogenized including bead-based grinding and subjected to liquid extraction according to Bligh and Dyer (Bligh \& Dyer, 1959). Analysis by flow injection ESIMS/MS using lipid class specific head group scans revealed huge differences between the individual samples. For example, we could find substantial concentrations of PG in some samples whereas other samples showed only minor PG content (Figure 2). Similar observations were made for other lipid classes. Additionally, the method of homogenization and extraction may greatly influence lipid species recovery. So sample preparation may determine whether analysis of lipids is confined to "easily accessible" lipids or includes also "hardly extractable" bacterial lipid. Bacterial lipids could be of particular interest since they are used as chemotaxonomic parameter to classify and identify bacterial (Busse, Denner, \& Lubitz, 1996). However, bacterial lipids also increase the complexity of the fecal lipidome. So a number of additional fatty acids usually not or only present at low concentrations in mammalian cells are found in bacteria such as branched chain, cyclopropane and hydroxyl fatty acids. In summary, an accurate analysis of the fecal lipidome poses a great challenge especially due to its high complexity and high variability. 
504 NMR has also been used for structural analyses and quantification of lipid

505 species including lipoproteins (Bou Khalil et al., 2010; Sander et al., 2013;

506 AlaKorpela et al., 1996; Fernando et al., 2010). ${ }^{31} \mathrm{P}-\mathrm{NMR}$ is an attractive method

507 to investigate phospholipid molecules due to the fact that all phospholipids have

508 at least one phosphorous nucleus and this NMR active isotope occurs at a natural

509 abundance of $100 \%$ and has got a high gyromagnetic ratio. Therefore, high

510 resolution ${ }^{31} \mathrm{P}-\mathrm{NMR}$ spectroscopy has successfully been employed to determine

511 the phospholipid composition of tissues and body fluids. Comprehensive reviews

512 with many applications can be found in the literature (Schiller \& Arnold, 2002;

513 Schiller et al., 2007). However, we could not identify any study that applied NMR

514 spectroscopy for lipid investigations in fecal samples.

515

516 Final considerations

517 It is noteworthy that although extremely useful and widely used, as illustrated by

518 this review, fecal materials reliably reflect the microbial activity of the distal

519 colon, which is moderately representative of the rest of the gastro-intestinal

520 tract. For example, although it is commonly accepted that SCFAs measured in

521 feces are an indicator of colonic production by gut bacteria, it is important to

522 remember that these metabolites are quickly absorbed by the intestinal

523 membrane and an increased detection in feces may also reflect a poorer

524 absorption. To overcome this issue, metabolic profiling techniques can be

525 applied on luminal content collected in various sections of the gastro-intestinal

526 track, although this implies a more invasive sample collection. Fecal water

527 profiling by NMR spectroscopy has been widely referenced for numerous animal

528 models such as rodents(Romick-Rosendale et al., 2009) and horses(Escalona et

529 al., 2014) as well as humans,(Jacobs et al., 2008) providing a database for future 
530 investigations. This is also extremely useful for similar evaluations performed on

531 fecal waters derived from in vitro batch cultures that simulate digestion by the

532 gut microbiota. Even if in vitro models are not a perfect representation of the

533 host-gut microbiota interplay, they provide a valuable overview of the microbial

534 activity in the gut in controlled conditions. For instance, metabolic profiling of

535 samples derived from such in vitro gut models has been recently applied to

536 compare the impact of diet on human and baboon gut microbial activity.(Frost,

537 Walton, Swann, \& Psichas, 2014)

538 Another important consideration when analyzing feces metabolome, and

539 particularly fecal bile acids, is the irregularity of bile secretion and the

540 inhomogeneity of fecal samples as carefully studied by Setchell et al., who

541 demonstrated that this was strongly correlated with diet patterns (Setchell et al.,

542 1987). This is particularly relevant to human studies since humans tend to have

543 a defined regular feeding pattern with set time and number of meals per day

544 (unlike rodents that tend to feed all night, and from time to time during the day).

545 As a consequence, it is recommended to analyze aliquots of thoroughly

546 homogenized $4-5$ day collections of feces.

547 Finally, since one of the main factors influencing the gut metabolic environment

548 is the microbiome, it is important to assess the microbial composition of the fecal

549 material when possible, using 16S rRNA sequencing or metagenomics when

550 possible, although these methods are not fully quantitative. Such metabolic

551 associations with gut bacteria should also be interpreted carefully as it is not

552 always possible to differentiate the host from the bacterial metabolic activity.

553 This is particularly true for amino acids that can be released by dead host cells or

554 be derived from protein digestion by host and bacterial enzymes. Typical 
555 bacterial metabolites include SCFAs, some organic acids such as formate and by-

556 products of protein degradation such as indole. However, many fecal metabolites

557 derive from host-bacterial co-metabolism, which is typically the case for

558 secondary and tertiary bile acids.

559

560 To summarize, the measurement of the fecal metabolome is becoming

561 increasingly popular as it provides an easy estimate of the diet-gut microbiota-

562 host metabolic interaction. However, there is a need for establishing clear

563 guidelines for fecal sample collection, preparation and analysis for metabolic

564 profiling. Both NMR and MS-based metabolic profiling are complementary

565 techniques and none of them to date is able to holistically assess the fecal

566 metabolome. Instead, it is recommended that a combination of methods is used

567 to extend the metabolic coverage.

568

569 Acknowledgements

570

571 The authors would like to thank Dr Lesli Hingstrup Larsen who provided the

572 sample for lipidomics analysis. This work was supported by the EU FP7

573 programme of research MyNewGut (613979).

574

575 
576

577

578

579

580

581

582

583

584

585

586

587

588

589

590

591

592

593

594

595

596

597 Benno, P., Midtvedt, K., Alam, M., Collinder, E., Norin, E., \& Midtvedt, T. (2005).

598 Examination of intestinal conversion of cholesterol to coprostanol in 633 healthy

599 subjects reveals an age- and sex-dependent pattern. Microbial Ecology in Health 600 and Disease, 17(4). 
601

602 Besten, den, G., van Eunen, K., Groen, A. K., \& Venema, K. (2013). The role of 603 short-chain fatty acids in the interplay between diet, gut microbiota, and host 604 energy metabolism. Journal of Lipid Research, 54(9), 2325-2340.

605

606 Bezabeh, T., Somorjai, R., Dolenko, B., Bryskina, N., Levin, B., Bernstein, C. N., \& 607 Smith, I. C. P. (2009). Detecting colorectal cancer by $1 \mathrm{H}$ magnetic resonance 608 spectroscopy of fecal extracts. NMR in Biomedicine, 22(6), 593-600.

609

610 Biagi, E., Candela, M., Fairweather-Tait, S., Franceschi, C., \& Brigidi, P. (2012).

611 Ageing of the human metaorganism: the microbial counterpart. Age, 34(1), 247612267.

613

614 Binder, M., Liebisch, G., Langmann, T., \& Schmitz, G. (2006). Metabolic profiling of 615 glycerophospholipid synthesis in fibroblasts loaded with free cholesterol and 616 modified low density lipoproteins. Journal of Biological Chemistry, 281(31), $617 \quad 21869-21877$.

618

619 Bjerrum, J. T., Wang, Y., Hao, F., Coskun, M., Ludwig, C., Günther, U., \& Nielsen, O. 620 H. (2014). Metabonomics of human fecal extracts characterize ulcerative colitis, 621 Crohn's disease and healthy individuals. Metabolomics, 11(1), 122-133. 622 http://doi.org/10.1007/s11306-014-0677-3

623

624 Bligh, E. G., \& Dyer, W. J. (1959). A rapid method of total lipid extraction and 625 purification. Canadian journal of biochemistry and physiology, 37(8), 911-917. 
627 Bou Khalil, M., Hou, W., Zhou, H., Elisma, F., Swayne, L. A., Blanchard, A. P., ... \& 628 Figeys, D. (2010). Lipidomics era: accomplishments and challenges. Mass 629 spectrometry reviews, 29(6), 877-929.

630

631 Busse, H. J., Denner, E. B., \& Lubitz, W. (1996). Classification and identification of 632 bacteria: current approaches to an old problem. Overview of methods used in 633 bacterial systematics. Journal of biotechnology, 47(1), 3-38.

634

635 Calvani, R., Brasili, E., Praticò, G., Capuani, G., Tomassini, A., Marini, F., ... \& 636 Miccheli, A. (2014). Fecal and urinary NMR-based metabolomics unveil an aging 637 signature in mice. Experimental gerontology, 49, 5-11.

638

639 Cao, G., Zhang, Y., Feng, J., Cai, H., Zhang, C., Ding, M., ... \& Cai, B. (2011). A Rapid 640 and sensitive assay for determining the main components in processed Fructus 641 corni by UPLC-Q-TOF-MS. Chromatographia, 73(1-2), 135-141.

642

643 Claesson, M. J., Cusack, S., O'Sullivan, O., Greene-Diniz, R., de Weerd, H., Flannery, 644 E., et al. (2011). Composition, variability, and temporal stability of the intestinal 645 microbiota of the elderly. Proceedings of the National Academy of Sciences, 108 646 Suppl 1, 4586-4591. http://doi.org/10.1073/pnas.1000097107

648 Claesson, M. J., Jeffery, I. B., Conde, S., Power, S. E., O’Connor, E. M., Cusack, S., ... \& 649 Fitzgerald, G. F. (2012). Gut microbiota composition correlates with diet and 650 health in the elderly. Nature, 488(7410), 178-184. 
651 Claus, S. P., \& Swann, J. R. (2013). Nutrimetabonomics: Applications for

652 Nutritional Sciences, with Specific Reference to Gut Microbial Interactions.

653 Annual Review of Food Science and Technology, 4, 381-399.

654 http://doi.org/10.1146/annurev-food-030212-182612

655

656 Claus, S. P., Ellero, S. L., Berger, B., Krause, L., Bruttin, A., Molina, J., et al. (2011).

657 Colonization-induced host-gut microbial metabolic interaction. mBio, 2(2).

658 http://doi.org/10.1128/mBio.00271-10

659

660 Claus, S. P., Tsang, T. M., Wang, Y., Cloarec, O., Skordi, E., Martin, F.-P., et al. 661 (2008). Systemic multicompartmental effects of the gut microbiome on mouse 662 metabolic phenotypes. Molecular Systems Biology, 4(1), 219. 663 http://doi.org/10.1038/msb.2008.56

664

665 Crowther, J. S., Drasar, B. S., Goddard, P., Hill, M. J., \& Johnson, K. (1973). The 666 effect of a chemically defined diet on the faecal flora and faecal steroid 667 concentration. Gut, 14(10), 790-793.

668

669 David, L. A., Maurice, C. F., Carmody, R. N., Gootenberg, D. B., Button, J. E., Wolfe, 670 B. E., et al. (2015). Diet rapidly and reproducibly alters the human gut 671 microbiome. Nature, 505(7484), 559-563. http://doi.org/10.1038/nature12820

673 Davies, J. M., Hua, H. U., Dheer, R., Martinez, M., Bhattacharya, S. K., \& Abreu, M. T. 674 (2014). Stool Phospholipid Signature is Altered by Diet and Tumors. PloS one, $6759(12)$, e114352, doi:10.1371/journal.pone.0114352 
677 Deda, O., Gika, H. G., Wilson, I. D., \& Theodoridis, G. A. (2015). An overview of

678 fecal sample preparation for global metabolic profiling. Journal of pharmaceutical 679 and biomedical analysis, 113, 137-150.

680

681 De Filippis, F., Pellegrini, N., Vannini, L., Jeffery, I. B., La Storia, A., Laghi, L., ... \& 682 Turroni, S. (2015). High-level adherence to a Mediterranean diet beneficially 683 impacts the gut microbiota and associated metabolome. Gut, gutjnl-2015.

684

685 Dixon, E., Clubb, C., Pittman, S., Ammann, L., Rasheed, Z., Kazmi, N., et al. (2011).

686 Solid-phase microextraction and the human fecal VOC metabolome. PLoS One, 687 6(4), e18471. doi:10.1371/journal.pone.0018471

688

689 Escalona, E. E., Leng, J., Dona, A. C., Merrifield, C. A., Holmes, E., Proudman, C. J., \& 690 Swann, J. R. (2015). Dominant components of the Thoroughbred metabolome 691 characterised by $1 \mathrm{H}$-nuclear magnetic resonance spectroscopy: A metabolite 692 atlas of common biofluids. Equine veterinary journal, 47(6), 721-730.

693

694 Evrard, E., \& Janssen, G. (1968). Gas-liquid chromatographic determination of 695 human fecal bile acids. Journal of Lipid Research, 9(2), 226-236.

697 Eyssen, H., \& Parmentier, G. (1974). Biohydrogenation of sterols and fatty acids 698 by the intestinal microflora. The American Journal of Clinical Nutrition, 27(11), 699 1329-1340. 
701 Fernando, H., Kondraganti, S., Bhopale, K. K., Volk, D. E., Neerathilingam, M.,

702 Kaphalia, B. S., ... \& Shakeel Ansari, G. A. (2010). 1H and 31P NMR lipidome of

703 ethanol-induced fatty liver. Alcoholism: Clinical and Experimental Research, 704 34(11), 1937-1947.

705

706 Flint, H. J., Duncan, S. H., Scott, K. P., \& Louis, P. (2015). Links between diet, gut 707 microbiota composition and gut metabolism. Proceedings of the Nutrition Society, 708 74(01), 13-22. http://doi.org/10.1017/S0029665114001463

709

710 Frost, G. S., Walton, G. E., Swann, J. R., Psichas, A., Costabile, A., Johnson, L. P., \&

711 Barraclough, T. G. (2014). Impacts of plant-based foods in Ancestral Hominin 712 diets on the metabolism and function of gut microbiota in vitro. Mbio, 5(3), 713 e00853-14.

714

715 Gao, X., Pujos-Guillot, E., \& Sébédio, J (2010). Development of a Quantitative 716 Metabolomic Approach to Study Clinical Human Fecal Water Metabolome Based 717 on Trimethylsilylation Derivatization and GC/MS Analysis. Analytical Chemistry, 718 82(15), 6447. doi:10.1021/ac1006552

719

720 Gao, X., Pujos-Guillot, E., Martin, J., Galan, P., Juste, C., Jia, W., \& Sébédio, J (2009).

721 Metabolite analysis of human fecal water by gas chromatography/mass 722 spectrometry with ethyl chloroformate derivatization. Analytical Biochemistry, 723 393(2), 163. doi:10.1016/j.ab.2009.06.036 
725 Gérard, P. (2013). Metabolism of cholesterol and bile acids by the gut microbiota.

726 Pathogens, 3(1), 14-24. http://doi.org/10.3390/pathogens3010014

727

728 Gregory, K. E., Bird, S. S., Gross, V. S., Marur, V. R., Lazarev, A. V., Walker, W. A., \& 729 Kristal, B. S (2013). Method Development for Fecal Lipidomics Profiling. 730 Analytical Chemistry, 85(2), 1114. doi:10.1021/ac303011k

731

732 Griffiths, W. J., \& Sjövall, J. (2010). Bile acids: analysis in biological fluids and 733 tissues. Journal of Lipid Research, 51(1), 23-41. 734 http://doi.org/10.1194/jlr.R001941-JLR200

735

736 Grundy, S. M., Ahrens, E. H., \& Davignon, J. (1969). The interaction of cholesterol 737 absorption and cholesterol synthesis in man. Journal of Lipid Research, 10(3), $738 \quad 304-315$.

739

740 Grundy, S. M., \& Ahrens, E. H. (1969). Measurements of cholesterol turnover, 741 synthesis, and absorption in man, carried out by isotope kinetic and sterol 742 balance methods. Journal of Lipid Research, 10(1), 91-107.

744 Grundy, S. M., \& Mok, H. Y. (1977). Determination of cholesterol absorption in 745 man by intestinal perfusion. Journal of Lipid Research, 18(2), 263-271.

747 Grundy, S. M., Ahrens, E. H., \& Miettinen, T. A. (1965). Quantitative isolation and 748 gas--liquid chromatographic analysis of total fecal bile acids. Journal of Lipid 749 Research, 6, 397-410. 
751 Hagey, L. R., \& Krasowski, M. D. (2013). Microbial biotransformations of bile 752 acids as detected by electrospray mass spectrometry. Advances in Nutrition 753 (Bethesda, Md.), 4(1), 29-35. http://doi.org/10.3945/an.112.003061

754

755 Hagio, M., Matsumoto, M., Fukushima, M., Hara, H., \& Ishizuka, S. (2009).

756 Improved analysis of bile acids in tissues and intestinal contents of rats using 757 LC/ESI-MS. Journal of Lipid Research, 50(1), 173-180. 758 http://doi.org/10.1194/jlr.D800041-JLR200

759

760 Han, J., Lin, K., Sequeira, C., \& Borchers, C. H. (2015). An isotope-labeled chemical 761 derivatization method for the quantitation of short-chain fatty acids in human 762 feces by liquid chromatography-tandem mass spectrometry. Analytica chimica 763 acta, 854, 86-94.

764

765 Hebel, T., Eisinger, K., Neumeier, M., Rein-Fischboeck, L., Pohl, R., Meier, E. M., ... \&

766 Krautbauer, S. (2015). Lipid abnormalities in alpha/beta2-syntrophin null mice 767 are independent from ABCA1. Biochimica et Biophysica Acta (BBA)-Molecular and 768 Cell Biology of Lipids, 1851(5), 527-536.

769

770 Hofmann, A. F., \& Eckmann, L. (2006). How bile acids confer gut mucosal 771 protection against bacteria. Proceedings of the National Academy of Sciences of 772 the United States of America, 103(12), 4333-4334. 773 http://doi.org/10.1073/pnas.0600780103 
775 Hofmann, A. F., \& Hagey, L. R. (2008). Bile acids: chemistry, pathochemistry,

776 biology, pathobiology, and therapeutics. Cellular and Molecular Life Sciences

777 (CMLS), 65(16), 2461-2483. http://doi.org/10.1007/s00018-008-7568-6

778

779 Hofmann, A. F. (2009). Bile acids: trying to understand their chemistry and

780 biology with the hope of helping patients. Hepatology, 49(5), 1403-1418.

781

782 Hofmann, A. F., Hagey, L. R., \& Krasowski, M. D. (2010). Bile salts of vertebrates:

783 structural variation and possible evolutionary significance. Journal of Lipid

784 Research, 51(2), 226-246. http://doi.org/10.1194/jlr.R000042

785

786 Hong, Y. S., Ahn, Y. T., Park, J. C., Lee, J. H., Lee, H., Huh, C. S., ... \& Hwang, G. S.

787 (2010). 1H NMR-based metabonomic assessment of probiotic effects in a colitis 788 mouse model. Archives of pharmacal research, 33(7), 1091-1101.

789

790 Jacobs, D. M., Deltimple, N., van Velzen, E., Van Dorsten, F. A., Bingham, M.,

791 Vaughan, E. E., \& van Duynhoven, J. (2008). 1H NMR metabolite profiling of feces

792 as a tool to assess the impact of nutrition on the human microbiome. NMR in

793 Biomedicine, 21(6), 615-626. http://doi.org/10.1002/nbm.1233

794

795 Jiménez-Girón, A., Ibáñez, C., Cifuentes, A., Simó, C., Muñoz-González, I., Martín-

796 Álvarez, P. J., ... \& Moreno-Arribas, M. (2015). Estudio del metaboloma fecal tras

797 el consumo moderado y continuado de vino tinro por individuos sanos. 
799 Kellogg, T. F., Knight, P. L., \& Wostmann, B. S. (1970). Effect of bile acid 800 deconjugation on the fecal excretion of steroids. Journal of lipid research, 11(4), $801 \quad 362-366$.

802

803 Korpela, J. T. (1982). Capillary gas-liquid chromatography of faecal free and 804 esterified neutral sterols. Scandinavian Journal of Clinical and Laboratory 805 Investigation, 42(6), 529-534.

806

807 Le Gall, G., Noor, S. O., Ridgway, K., Scovell, L., Jamieson, C., Johnson, I. T., et al. 808 (2011). Metabolomics of Fecal Extracts Detects Altered Metabolic Activity of Gut 809 Microbiota in Ulcerative Colitis and Irritable Bowel Syndrome. Journal of 810 Proteome Research, 10(9), 4208-4218. http://doi.org/10.1021/pr2003598

811

812 Le Roy, C. I., Štšepetova, J., Sepp, E., Songisepp, E., Claus, S. P., \& Mikelsaar, M. 813 (2015). New insights into the impact of Lactobacillus population on host-bacteria 814 metabolic interplay. Oncotarget, 6(31), 30545-30556.

815

816 Leidl, K., Liebisch, G., Richter, D., \& Schmitz, G. (2008). Mass spectrometric 817 analysis of lipid species of human circulating blood cells. Biochimica et 818 Biophysica Acta (BBA)-Molecular and Cell Biology of Lipids, 1781(10), 655-664.

820 Li, J. V., Saric, J., Wang, Y., Keiser, J., Utzinger, J., \& Holmes, E. (2011). 821 Chemometric analysis of biofluids from mice experimentally infected with 822 Schistosoma mansoni. Parasites \& Vectors, 4, 179. http://doi.org/10.1186/1756$823 \quad 3305-4-179$ 
825 Lichtenstein, A. H. (1990). Intestinal cholesterol metabolism. Annual medicine $82622(1)$

828 Liebisch, G., Vizcaíno, J. A., Köfeler, H., Trötzmüller, M., Griffiths, W. J., Schmitz, G., 829 \& Wakelam, M. J. (2013). Shorthand notation for lipid structures derived from 830 mass spectrometry. Journal of lipid research, jlr-M033506.

831

832 Lozupone, C. A., Stombaugh, J. I., Gordon, J. I., Jansson, J. K., \& Knight, R. (2012).

833 Diversity, stability and resilience of the human gut microbiota. Nature, 834 489(7415), 220-230.

835

836 Lütjohann, D., Meese, C. O., Crouse, J. R., \& Bergmann, von, K. (1993). Evaluation 837 of deuterated cholesterol and deuterated sitostanol for measurement of 838 cholesterol absorption in humans. Journal of Lipid Research, 34(6), 1039-1046.

839

840 Marchesi, J. R., Holmes, E., Khan, F., Kochhar, S., Scanlan, P., Shanahan, F., ... \&

841 Wang, Y. (2007). Rapid and noninvasive metabonomic characterization of 842 inflammatory bowel disease. Journal of proteome research, 6(2), 546-551.

843

844 Martin, F.-P. J., Sprenger, N., Montoliu, I., Rezzi, S., Kochhar, S., \& Nicholson, J. K. 845 (2010). Dietary modulation of gut functional ecology studied by fecal 846 metabonomics. Journal of Proteome Research, 9(10), 5284-5295. 847 http://doi.org/10.1021/pr100554m 
849 Meiboom, S., \& Gill, D. (1958). Modified Spin-Echo Method for Measuring Nuclear

850 Relaxation Times. Review of Scientific Instruments, 29(8), 688.

851 http://doi.org/10.1063/1.1716296

852

853 Midtvedt, T., Lingaas, E., Carlstedt-Duke, B., Höverstad, T., Midtvedt, A. C.,

854 Saxerholt, H., et al. (1990). Intestinal microbial conversion of cholesterol to 855 coprostanol in man. Influence of antibiotics. APMIS : Acta Pathologica, 856 Microbiologica, Et Immunologica Scandinavica, 98(9), 839-844.

857

858 Miettinen, T. A., Ahrens, E. H., \& Grundy, S. M. (1965). Quantitative isolation and 859 gas-liquid chromatographic analysis of total dietary and fecal neutral steroids. 860 Journal of Lipid Research, 6, 411-424.

861

862 Monleon, D., Morales, J. M., Barrasa, A., Lopez, J. A., Vazquez, C., \& Celda, B. 863 (2009). Metabolite profiling of fecal water extracts from human colorectal 864 cancer. NMR in Biomedicine, 22(3), 342-348.

865

866 Mukherji, A., Kobiita, A., Ye, T., \& Chambon, P. (2013). Homeostasis in intestinal 867 epithelium is orchestrated by the circadian clock and microbiota cues 868 transduced by $\longrightarrow$ TLRs. Cell, 153(4), 812-827.

869 http://doi.org/10.1016/j.cell.2013.04.020

870

871 Ndagijimana, M., Laghi, L., Vitali, B., Placucci, G., Brigidi, P., \& Guerzoni, M. E. 872 (2009). Effect of a synbiotic food consumption on human gut metabolic profiles 
873 evaluated by $1 \mathrm{H}$ Nuclear Magnetic Resonance spectroscopy. International 874 journal of food microbiology, 134(1), 147-153.

875

876 O'Hara, A. M., \& Shanahan, F. (2006). The gut flora as a forgotten organ. EMBO

877 Reports, 7(7), 688-693. http://doi.org/10.1038/sj.embor.7400731

878

879 Owen, R. W., Thompson, M. H., \& Hill, M. J. (1984). Analysis of metabolic profiles 880 of steroids in faeces of healthy subjects undergoing chenodeoxycholic acid 881 treatment by liquid-gel chromatography and gas-liquid chromatography-mass 882 spectrometry. Journal of Steroid Biochemistry, 21(5), 593-600.

883

884 Palmer, C., Bik, E. M., DiGiulio, D. B., Relman, D. A., \& Brown, P. O. (2007). 885 Development of the human infant intestinal microbiota. PLoS Biol, 5(7), e177.

886

887 Perwaiz, S., Mignault, D., Tuchweber, B., \& Yousef, I. M. (2002). Rapid and 888 improved method for the determination of bile acids in human feces using MS. 889 Lipids, 37(11), 1093-1100.

890

891 Phua, L. C., Chue, X. P., Koh, P. K., Cheah, P. Y., Ho, H. K., \& Chan, E. C. Y. (2014). 892 Non-invasive fecal metabonomic detection of colorectal cancer. Cancer biology \& 893 therapy, 15(4), 389-397.

894

895 Phua, L. C., Koh, P. K., Cheah, P. Y., Ho, H. K., \& Chan, E. C. Y. (2013). Global gas 896 chromatography/time-of-flight mass spectrometry (GC/TOFMS)-based 
897 metabonomic profiling of lyophilized human feces. Journal of Chromatography B, 937, 103-113.

899

900 Ridlon, J. M., Kang, D.-J., \& Hylemon, P. B. (2006). Bile salt biotransformations by

901 human intestinal bacteria. Journal of Lipid Research, 47(2), 241-259.

902 http://doi.org/10.1194/jlr.R500013-JLR200

903

904 Romick-Rosendale, L. E., Goodpaster, A. M., Hanwright, P. J., Patel, N. B., Wheeler, 905 E. T., Chona, D. L., \& Kennedy, M. A. (2009). NMR-based metabonomics analysis 906 of mouse urine and fecal extracts following oral treatment with the broad907 spectrum antibiotic enrofloxacin (Baytril). Magnetic Resonance in Chemistry: 908 MRC, 47 Suppl 1, S36-46. http://doi.org/10.1002/mrc.2511

909

910 Saric, J., Wang, Y., Li, J., Coen, M., Utzinger, J., Marchesi, J. R., et al. (2008). Species

911 variation in the fecal metabolome gives insight into differential gastrointestinal 912 function. Journal of Proteome Research, 7(1), 352-360. 913 http://doi.org/10.1021/pr070340k

914

915 Sayin, S. I., Wahlström, A., Felin, J., Jäntti, S., Marschall, H.-U., Bamberg, K., et al. 916 (2013). Gut Microbiota Regulates Bile Acid Metabolism by Reducing the Levels of 917 Tauro-beta-muricholic Acid, a Naturally Occurring FXR Antagonist. Cell 918 Metabolism, 17(2), 225-235. http://doi.org/10.1016/j.cmet.2013.01.003 
920 Scherer, M., Böttcher, A., \& Liebisch, G. (2011). Lipid profiling of lipoproteins by

921 electrospray ionization tandem mass spectrometry. Biochimica et Biophysica

922 Acta (BBA)-Molecular and Cell Biology of Lipids, 1811(11), 918-924.

923

924 Schiller, J., \& Arnold, K. (2002). Application of high resolution 31P NMR

925 spectroscopy to the characterization of the phospholipid composition of tissues

926 and body fluids-a methodological review. Medical Science Monitor, 8(11),

927 MT205-MT222.

928

929 Schiller, J., Muller, M., Fuchs, B., Arnold, K., \& Huster, D. (2007). 31P NMR

930 spectroscopy of phospholipids: From micelles to membranes. Current Analytical

931 Chemistry, 3(4), 283-301.

932

933 SScott, K. P., Duncan, S. H., \& Flint, H. J. (2008). Dietary fibre and the gut 934 microbiota. Nutrition Bulletin, 33(3), 201-211.

935

936 Setchell, K. D., Lawson, A. M., Tanida, N., \& Sjövall, J. (1983). General methods for

937 the analysis of metabolic profiles of bile acids and related compounds in feces.

938 Journal of Lipid Research, 24(8), 1085-1100

939

940 Sigruener, A., Kleber, M. E., Heimerl, S., Liebisch, G., Schmitz, G., \& Maerz, W.

941 (2014). Glycerophospholipid and sphingolipid species and mortality: the

942 Ludwigshafen Risk and Cardiovascular Health (LURIC) study. PloS one, 9(1), $943 \mathrm{e} 85724$. 
945 Sonnenburg, E. D., \& Sonnenburg, J. L. (2014). Starving our Microbial Self: The

946 Deleterious Consequences of a Diet Deficient in Microbiota-Accessible

947 Carbohydrates. Cell Metabolism, 20(5), 779-786.

948 http://doi.org/10.1016/j.cmet.2014.07.003

949

950 Snog-Kjaer, A., Prange, I., \& Dam, H. (1956). Conversion of cholesterol into 951 coprosterol by bacteria in vitro. Journal of General Microbiology, 14(2), 256-260.

952

953 Spritz, N., Ahrens, E. H., \& Grundy, S. (1965). Sterol balance in man as plasma

954 cholesterol concentrations are altered by exchanges of dietary fats. Journal of 955 clinical investigation, 44(9), 1482-1493.

956

957 Story, J. A., \& Furumoto, E. J. (1991). Bile acid analysis: methods and problems.

958 European Journal of Cancer Prevention : the Official Journal of the European 959 Cancer Prevention Organisation (ECP), 1 Suppl 2, 29-33.

960

961 Su, X., Wang, N., Chen, D., Li, Y., Lu, Y., Huan, T., \& Li, L. (2016). Dansylation

962 isotope labeling liquid chromatography mass spectrometry for parallel profiling

963 of human urinary and fecal submetabolomes. Analytica chimica acta, 903, 100964109.

965

966 Tian, Y., Zhang, L., Wang, Y., \& Tang, H. (2011). Age-related topographical 967 metabolic signatures for the rat gastrointestinal contents. Journal of proteome 968 research, 11(2), 1397-1411. 
970 Trauner, M., Claudel, T., Fickert, P., Moustafa, T., \& Wagner, M. (2010). Bile acids

971 as regulators of hepatic lipid and glucose metabolism. Digestive Diseases, 28(1),

972 220-224.

973

974 Voigt, R. M., Forsyth, C. B., Green, S. J., Mutlu, E., Engen, P., Vitaterna, M. H., et al. 975 (2014). Circadian disorganization alters intestinal microbiota. PloS One, 9(5), 976 e97500. http://doi.org/10.1371/journal.pone.0097500

977

978 Weir, T. L., Manter, D. K., Sheflin, A. M., Barnett, B. A., Heuberger, A. L., \& Ryan, E. 979 P. (2013). Stool microbiome and metabolome differences between colorectal 980 cancer patients and healthy adults. PloS one, 8(8), e70803.

981

982 Wenk, M. R. (2010). Lipidomics: New Tools and Applications. Cell, 143(6), 888983 895. http://doi.org/10.1016/j.cell.2010.11.033

984

985 Wu, J., An, Y., Yao, J., Wang, Y., \& Tang, H. (2010). An optimised sample 986 preparation method for NMR-based faecal metabonomic analysis. Analyst, 987 135(5), 1023-1030.

988

989 Yap, I. K. S., Li, J. V., Saric, J., Martin, F.-P., Davies, H., Wang, Y., et al. (2008). 990 Metabonomic and microbiological analysis of the dynamic effect of vancomycin991 induced gut microbiota modification in the mouse. Journal of Proteome Research, 992 7(9), 3718-3728. http://doi.org/10.1021/pr700864x 993 
994 Yatsunenko, T., Rey, F. E., Manary, M. J., Trehan, I., Dominguez-Bello, M. G., 995 Contreras, M., et al. (2012). Human gut microbiome viewed across age and 996 geography. Nature, 486(7402), 222-227. http://doi.org/10.1038/nature11053 997

998 Zhao, Y. Y., Zhang, L., Long, F. Y., Cheng, X. L., Bai, X., Wei, F., \& Lin, R. C. (2013). 999 UPLC-Q-TOF/HSMS/MS E-based metabonomics for adenine-induced changes in 1000 metabolic profiles of rat faeces and intervention effects of ergosta-4, 6, 8 (14), 1001 22-tetraen-3-one. Chemico-biological interactions, 201(1), 31-38.

1002

1003 Zhao, Y., Wu, J., Li, J. V., Zhou, N. Y., Tang, H., \& Wang, Y. (2013). Gut microbiota 1004 composition modifies fecal metabolic profiles in mice. Journal of proteome 1005 research, 12(6), 2987-2999.

1006

1007 Zheng, X., Qiu, Y., Zhong, W., Baxter, S., Su, M., Li, Q., ... \& Zeisel, S. H. (2013). A 1008 targeted metabolomic protocol for short-chain fatty acids and branched-chain 1009 amino acids. Metabolomics, 9(4), 818-827.

1010

1011 


\section{FIGURE CAPTIONS}

1013 Figure 1: Estimated proportion of fecal cholesterol derivatives in humans.

1014

1015 Figure 2: Neutral loss (NL) of 189 of lipid extracts prepared from fecal samples. 1016 Suspensions of human fecal samples in water/methanol (1/1) were subjected to 1017 bead-based homogenization. Homogenates were extracted according to Bligh 1018 and Dyer (Bligh \& DYER, 1959). Crude lipid extracts were analyzed by direct 1019 flow injection analysis as described previously (Matyash et al., 2008). Displayed 1020 are NL 189 spectra, specific for phosphatidylglycerol (PG), of three different 1021 samples normalized to the highest intensity.

1023 Table 1: Summary of published studies applying metabolomics to study fecal 1024 samples using NMR and MS platforms. Summary of protocols and main outcomes 1025 are included.

1026 Key: GC-FID: Gas chromatography- Flame ionization detector; GC-MS: Gas 1027 chromatography-Mass spectrometry; LC-MS: Liquid chromatography-Mass 1028 spectrometry; UPLC-MS: Ultra-Performance Liquid Chromatography-Mass 1029 spectrometry 


\begin{tabular}{|c|c|c|c|c|c|c|}
\hline $\begin{array}{l}\text { Analytical } \\
\text { technique }\end{array}$ & Study aim & $\begin{array}{c}\text { Sample } \\
\text { preparation } \\
\text { overview }\end{array}$ & Material / buffer & Measurement & Main results & References \\
\hline \multirow[t]{2}{*}{ NMR $400 \mathrm{MHz}$} & Aging in mice & $\begin{array}{l}\text { 1:4 (wN/Av) feces } \\
\text { in deuterated PBS + } \\
\text { two filtration step }\end{array}$ & $\begin{array}{l}60 \mu \mathrm{L} \text { deuterated PBS } \\
\text { containing } 2 \mathrm{mM} \text { TSP in } \\
600 \mu \mathrm{L} \text { of extract }\end{array}$ & TOCSY \& HSQC & $\begin{array}{l}\text { Aging induces } \uparrow 4 \text { - } \\
\text { hydroxyphenylacetate, histidine, } \\
\text { formate, succinate and } \downarrow \text { - }\end{array}$ & $\begin{array}{l}\text { Calvani et al., } \\
2014\end{array}$ \\
\hline & $\begin{array}{l}\text { Colorectal cancer } \\
\text { human }\end{array}$ & $\begin{array}{l}1: 3(\mathrm{wN} / \mathrm{Av}) \text { feces } \\
\text { in deuterated PBS + } \\
\text { vortexing and } \\
\text { centrifugation }\end{array}$ & $\begin{array}{l}50 \mu \mathrm{L} \text { TSP }(4 \mathrm{mM}) \text { in D2O } \\
\text { added in } 500 \mu \mathrm{L} \\
\text { supernatant }\end{array}$ & $\mathrm{N} / \mathrm{A}$ & $\mathrm{N} / \mathrm{A}$ & $\begin{array}{l}\text { Bezabeh et al. } \\
2009\end{array}$ \\
\hline NMR $500 \mathrm{MHz}$ & $\begin{array}{l}\text { Experimental } \\
\text { optimisation, mice }\end{array}$ & $\begin{array}{l}1: 10 \mathrm{mg} \cdot \mu \mathrm{L}-1 \\
\text { feces-to-buffer } \\
\text { ratio, tissuelyser }\end{array}$ & $\mathrm{N} / \mathrm{A}$ & $\begin{array}{l}\text { COSY, TOCSY, HSQC, } \\
\text { HMBC }\end{array}$ & Identification of 40 metabolites & $\begin{array}{l}\text { Wu el al., } \\
2010\end{array}$ \\
\hline \multirow[t]{4}{*}{ NMR $600 \mathrm{MHz}$} & $\begin{array}{l}\text { Ulcetative colitis } \\
\text { activity, humans }\end{array}$ & $\begin{array}{l}1: 2(\mathrm{WN} / \mathrm{Av}) \text { feces } \\
\text { to PBS, vortexing, } \\
\text { cenrifugation and } \\
\text { filtration }\end{array}$ & $\begin{array}{l}4 \mu \mathrm{L} \text { of } \mathrm{D} 2 \mathrm{ON} / \mathrm{A} 500 \mu \mathrm{M} \\
\text { TSP with } 40 \mu \mathrm{L} \text { of fecal } \\
\text { extract }\end{array}$ & CPMG & $\begin{array}{l}\text { Active UC induces } \uparrow \text { BCAAs, } \\
\text { lysine, alanine, taurine }\end{array}$ & $\begin{array}{l}\text { Bjerrum et al. } \\
2014\end{array}$ \\
\hline & $\begin{array}{l}\text { Antiobiotic } \\
\text { treatment } \\
\text { (gentamicine, } \\
\text { ceftriaxone), mice }\end{array}$ & $\begin{array}{l}\text { 1:10 feces to PBS, } \\
\text { freeze-thaw } \\
\text { treatment, } \\
\text { tissuelysr, } \\
\text { centrifugation }\end{array}$ & $\begin{array}{l}30 \% \text { D2O, } 0.002 \% \text { TSP, } \\
0.03 \% \\
\text { of Na3N (wN/Av) }\end{array}$ & $\begin{array}{l}\text { COSY, TOCSY, JRES, } \\
\text { HSQC, HMBC }\end{array}$ & $\begin{array}{l}\text { Antibiotic induces } \uparrow \\
\text { oligosacharides. phenolic acids } \\
\text { and } \downarrow \text { SCFAs, uracil, } \\
\text { hypoxanthine }\end{array}$ & $\begin{array}{l}\text { Zhao et al., } \\
2013\end{array}$ \\
\hline & Age, rat & $\begin{array}{l}\text { 1:10 feces to PBS, } \\
\text { vortexing, freeze- } \\
\text { thaw, tissuelyser, } \\
\text { centrifugation }\end{array}$ & $\begin{array}{l}0.1 \mathrm{M} \\
\mathrm{K} 2 \mathrm{HPO} 4 \mathrm{~N} / \mathrm{ANaH} 2 \mathrm{PO} 4, \mathrm{pH} \\
=7.4 \text {, containing } 10 \% \\
\mathrm{D} 2 \mathrm{O}, 0.58 \mathrm{mM} \text { TSP }\end{array}$ & $\begin{array}{l}\text { COSY, TOCSY, HSQC, } \\
\text { HMBC, DOSY }\end{array}$ & $\begin{array}{l}\text { Aging induces } \downarrow \text { arabinose, } \\
\text { xylose, galactose, arabinoxylan, } \\
\text { propionate and inosine and } \uparrow \\
\text { taurine, xylose, arabinose, } \\
\text { galactose, } \\
\text { arabinoxylans }\end{array}$ & $\begin{array}{l}\text { Tian et al., } \\
2012\end{array}$ \\
\hline & $\begin{array}{l}\text { Infection } \\
\text { Schistosoma }\end{array}$ & $\begin{array}{l}2 \text { fecal pellets } \\
\text { homogenized in }\end{array}$ & PBS containing $0.01 \%$ TSP & CPMG, COSY, TOCSY & $\begin{array}{l}\text { Infection induces } \uparrow 5 \text { - } \\
\text { Aminovalerate, SCFAs }\end{array}$ & Li et al., 2011 \\
\hline
\end{tabular}


mansoni, mice

$700 \mu \mathrm{L}$ PBS,

sonication,

centrifugation

IBS and UC,

human

1:50 (wN/Av) feces

to PBS,

centrifugation,

filtration

ProN/Aprebiotics, $\quad 1: 12$ (wN/Av)

mice

mashed feces to

PBS, centrifugation

added in $600 \mu \mathrm{L}$

supernatant

Colorectal cancer,

$1: 2$ feces to

distilled water

homogenization,

freezing, thawing,

centrifugation

Grape juce and

$1: 20$ (wN/Av) feces

wine extract

to cold D2O or

CD3OD, vortexing,

human centrifugation

Effect of Species

$\mathrm{N} / \mathrm{A}$

storage,

lyophilization,

sonication,

filatrtiona nd

homognisation

UC, human

deuterated PBS

fecal water

$1 \mathrm{mM}$ TSP

N/A

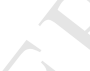

$1: 2(w N / A v)$ feces containing $1 \mathrm{mM}$ TSP

COSY, HSQC, HMBC

TOCSY,HMBC,HSQC

$100 \mu \mathrm{L} D 20$ to $500 \mu \mathrm{L}$

TOCSY

D2O or CD3OD containing

CPMG

COSY, TOCSY, HSQC,

$\mathrm{HMBC}$ to PBS, vortexing,

filtration,

centrifugation
$\& 0.01 \%$ TSP) in $400 \mu$

fecal water
COSY, TOCSY (propionate)

UC induces $\uparrow$ taurine and

cadaverine, IBS induces $\uparrow$ bile acids and $\downarrow$ BCFAs

Prebiotic induces $\downarrow$ threonine, alanine, glutamate, glutamine, aspartate, lysine, lycine,

butyrate, uracil, hypoxanthine and $\boldsymbol{\uparrow}$ monosaccharides, glucose, trimethylamine. Pre and probiotic $\downarrow$ trimethylamine and $\uparrow$ acetate, butyrate, glutamine Cancer induces $\downarrow$ acetate, butyrate

Monleon et al., 2009

Grape juce consumption + wine induces $\downarrow$ isobutyrate

Jacobs et al., 2008

torage: $\uparrow$ alanine, glutamate,

Saric et al. threonine, aspartic acid, BCAAs, glucose. Lyophilization: $\uparrow$ BCAAs and $\downarrow$ succinate, SCFAs.

Sonication: $\uparrow$ uracil, glucose and $\downarrow$ SCFAs

UC induces $\boldsymbol{\Downarrow}$ acetate, butyrate, methylamine, TMA and $\uparrow$

Marchesi et isoleucine, leucine, lusine
Le Gall et al.

Hong et al., 2010 


\begin{tabular}{|c|c|c|c|c|c|c|}
\hline NMR $700 \mathrm{MHz}$ & Lactobacillus & $\begin{array}{l}\text { 1:2 }(\mathrm{wN} / \mathrm{Av}) \text { feces } \\
\text { to detarated PBS, } \\
\text { tissue lyser, } \\
\text { centrifugation }\end{array}$ & $\begin{array}{l}\text { Fecal water extracted in } \\
\text { 9:1 D2ON/AH2O and } 0.05 \\
\% \text { TSP }\end{array}$ & Noesy & $\begin{array}{l}\text { L. helveticus induces } \uparrow \text { butyrate, } \\
\text { lactate and incresed Lactobacillus } \\
\text { level induces } \uparrow \text { phenylalanine, } \\
\text { tyrosine, lysine, lactate, } \\
\text { propionate, valine, leucine, } \\
\text { isoleucine, butyrate, acetate. }\end{array}$ & $\begin{array}{l}\text { Le Roy et al., } \\
2015\end{array}$ \\
\hline NMR $850 \mathrm{MHz}$ & $\begin{array}{l}\text { Baytrill treatment, } \\
\text { mice }\end{array}$ & $\begin{array}{l}1: 2(\mathrm{wN} / \mathrm{Av}) \text { feces } \\
\text { to PBS, vortexing, } \\
\text { centrifugation }\end{array}$ & $\begin{array}{l}200 \mu \mathrm{L} \text { buffer } 10 \% \mathrm{D} 20 \\
\text { and } 0.01 \% \text { TSP in } 400 \mu \mathrm{L} \\
\text { fecal water }\end{array}$ & CPMG & $\begin{array}{l}\text { Treament induces } \downarrow \text { alanine, } \\
\text { butyrate, isoleucine, leucine, } \\
\text { propionate, threonine, valine and } \\
\uparrow \text { urea }\end{array}$ & $\begin{array}{l}\text { Romick- } \\
\text { Rosendale et } \\
\text { al., } 2009\end{array}$ \\
\hline \multirow[t]{4}{*}{ GC-MS } & $\begin{array}{l}\text { Colorectal cancer } \\
\text { human }\end{array}$ & $\begin{array}{l}\text { oximation and } \\
\text { silylation }\end{array}$ & lyophilized human feces & N/A & $\begin{array}{l}\text { Cancer patients } \downarrow \text { butyrate, poly } \\
\text { and monounsaturated fatty } \\
\text { acids, ursodeoxycholic acid and } \\
\uparrow \text { acetate, amino acids }\end{array}$ & $\begin{array}{l}\text { Weir et al., } \\
2013\end{array}$ \\
\hline & $\begin{array}{l}\text { VOCs irritable } \\
\text { bowel syndrome, } \\
\text { active Crohn's } \\
\text { disease, ulcerative } \\
\text { colitis }\end{array}$ & SPME & human feces & N/A & $\begin{array}{l}240 \text { metabolites; esters of short } \\
\text { chain fatty acids, } \\
\text { cyclohexanecarboxylic } \\
\text { acid associated with irritable } \\
\text { bowel syndrome }\end{array}$ & $\begin{array}{l}\text { Ahmed, } \\
\text { Greenwood, } \\
\text { de Lacy } \\
\text { Costello, } \\
\text { Ratcliffe, \& } \\
\text { Probert, } 2013\end{array}$ \\
\hline & technical paper & trimethylsilylation & human fecal water & $\mathrm{N} / \mathrm{A}$ & $\begin{array}{l}133 \text { compounds structurally } \\
\text { confirmed; } 33 \text { quantified }\end{array}$ & $\begin{array}{l}\text { Gao, Pujos- } \\
\text { Guillot, \& } \\
\text { Sébédio, } 2010\end{array}$ \\
\hline & technical paper & $\begin{array}{l}\text { ethyl } \\
\text { chloroformate } \\
\text { derivatization } \\
\end{array}$ & human fecal water & $\mathrm{N} / \mathrm{A}$ & $\begin{array}{l}73 \text { compounds identified; } 34 \\
\text { validated by reference standards }\end{array}$ & $\begin{array}{l}\text { Gao et al., } \\
2009\end{array}$ \\
\hline \multirow[t]{2}{*}{ GC-TOF-MS } & technical paper & $\begin{array}{l}\text { oximation and } \\
\text { silylation }\end{array}$ & lyophilized human feces & $\mathrm{N} / \mathrm{A}$ & $\begin{array}{l}107 \text { metabolites matched with } \\
\text { mass spectra libraries, influence } \\
\text { of blood on fecal metabolome }\end{array}$ & $\begin{array}{l}\text { Phua, Koh, } \\
\text { Cheah, Ho, \& } \\
\text { Chan, } 2013\end{array}$ \\
\hline & $\begin{array}{l}\text { Colorectal cancer } \\
\text { human }\end{array}$ & $\begin{array}{l}\text { oximation and } \\
\text { silylation }\end{array}$ & lyophilized human feces & N/A & $\begin{array}{l}\text { fecal metabolomic profiles of } \\
\text { patients clearly differ from } \\
\text { healthy subjects }\end{array}$ & $\begin{array}{l}\text { Phua et al., } \\
2014\end{array}$ \\
\hline GC-MS, GC-FID & $\begin{array}{l}\text { VOCs, technical } \\
\text { paper }\end{array}$ & SPME & human feces & N/A & $\begin{array}{l}\text { evaluation of eight different } \\
\text { commercially available SPME }\end{array}$ & $\begin{array}{l}\text { Dixon et al., } \\
2011\end{array}$ \\
\hline
\end{tabular}




\begin{tabular}{|c|c|c|c|c|c|c|}
\hline $\begin{array}{l}\text { UPLC- } \\
\text { MSN/ATOF-MS }\end{array}$ & $\begin{array}{l}\text { liver cirrhosis, } \\
\text { hepatocellular } \\
\text { carcinoma }\end{array}$ & $\begin{array}{l}\text { homogenization, } \\
\text { centrifugation, } \\
\text { filtration }\end{array}$ & human feces & $\mathrm{N} / \mathrm{A}$ & $\begin{array}{l}\text { Cancer patients } \downarrow \\
\text { chenodeoxycholic acid, 7- } \\
\text { ketolithocholic acid, } \\
\text { urobilinogen, urobilin and } \uparrow \\
\text { lysophosphatidylcholine (LPC) } \\
\text { 16:0 and 18:0 }\end{array}$ & $\begin{array}{l}\text { Cao et al., } \\
2011\end{array}$ \\
\hline UHPLC-TOF-MS & $\begin{array}{l}\text { Effect of } \\
\text { consumption of } \\
\text { red wine }\end{array}$ & $\begin{array}{l}\text { mixing with saline } \\
\text { solution, } \\
\text { centrifugation, } \\
\text { filtration }\end{array}$ & human feces & $\mathrm{N} / \mathrm{A}$ & $\begin{array}{l}37 \text { metabolites related to wine } \\
\text { intake }\end{array}$ & $\begin{array}{l}\text { Jiménez-Girón } \\
\text { et al., } 2015\end{array}$ \\
\hline UPLC-Q-TOF-MS & $\begin{array}{l}\text { chronic renal } \\
\text { failure }\end{array}$ & $\begin{array}{l}\text { homogenization, } \\
\text { extraction with } \\
\text { acetonitrile }\end{array}$ & rat feces & & $\begin{array}{l}\text { renal failure } \uparrow \\
\text { chenodeoxychrolic acid, palmitic } \\
\text { acid, adenine, phytosphingosine, } \\
\text { monoglycerol } 24: 1,12 \text {-hydroxy- } \\
\text { 3-oxochola- } \\
\text { dienic acid, } \\
\text { lysophosphatidylethanolamine } \\
\text { 18:2 and } 16: 0 \text { and } \downarrow \text { 7- } \\
\text { ketolithocholic acid }\end{array}$ & $\begin{array}{l}\text { Zhao, Cheng, } \\
\text { Wei, Bai, \& } \\
\text { Lin, } 2012\end{array}$ \\
\hline LC-MS, LC-UV & technical paper & $\begin{array}{l}\text { Dried fecal samples } \\
\text { extraction with } \\
\text { water and } \\
\text { acetonitrile, } \\
\text { derivatization with } \\
\text { dansyl chloride }\end{array}$ & human feces & $\mathrm{N} / \mathrm{A}$ & $\begin{array}{l}67 \text { metabolites (mainly amino } \\
\text { acids) identified }\end{array}$ & Su et al., 2015 \\
\hline
\end{tabular}




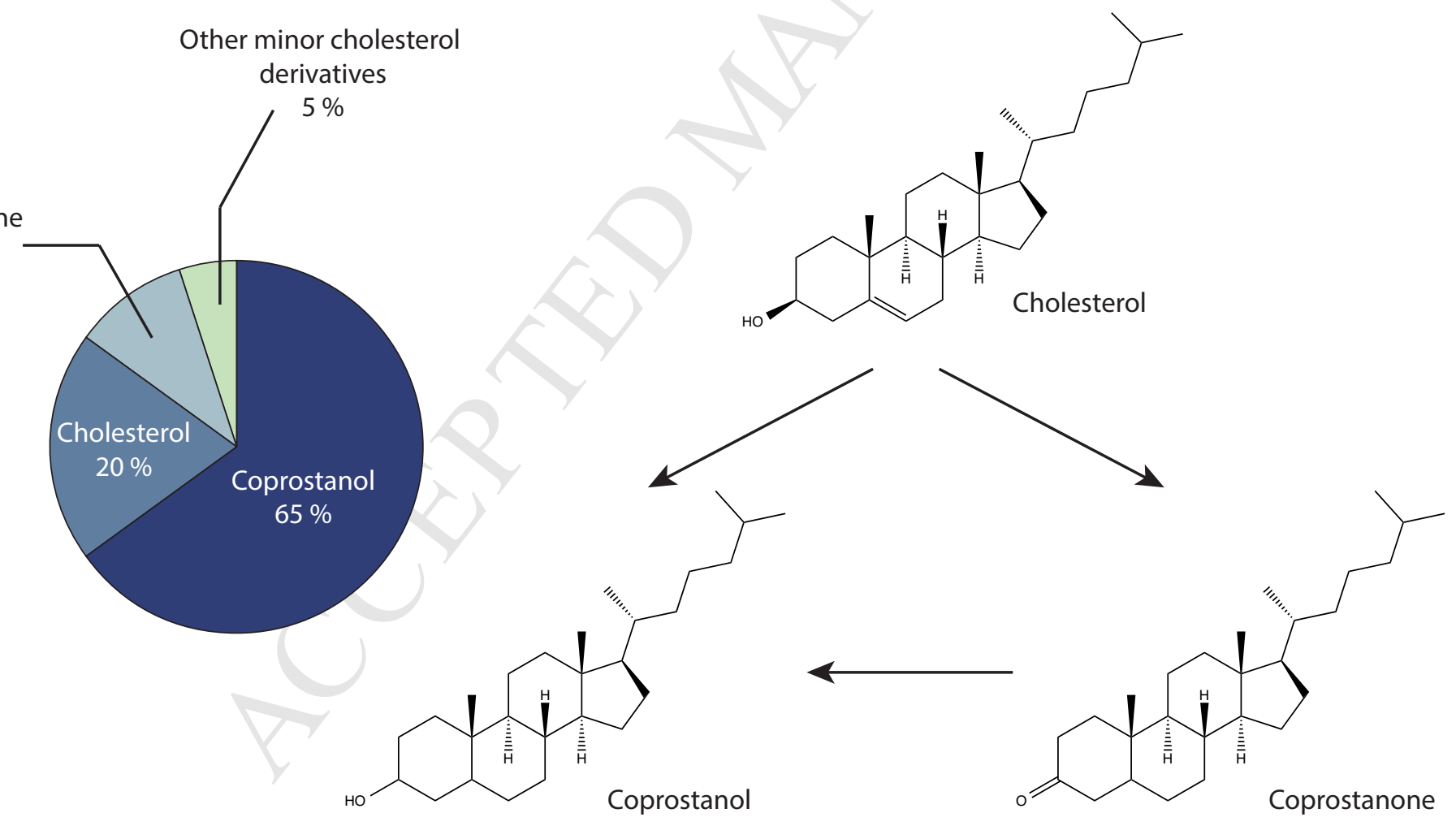

Minoor fecal cholesterol derivatives
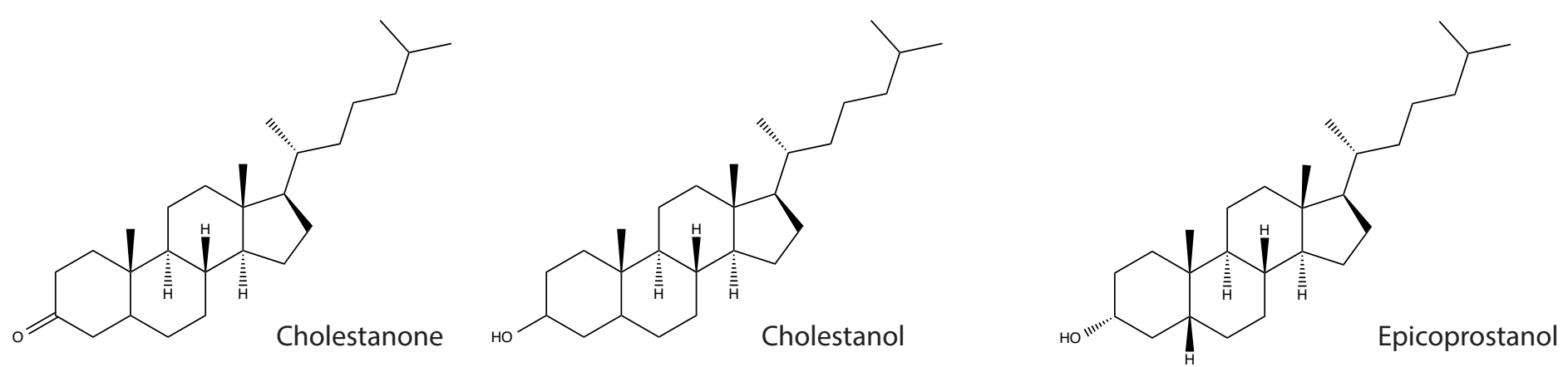


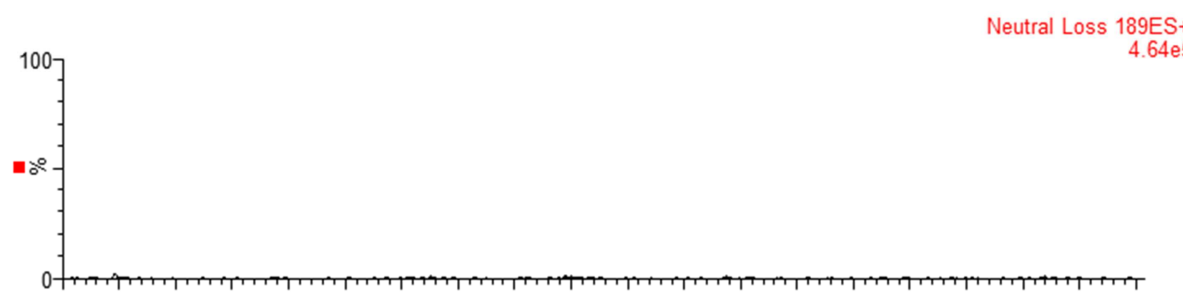

Neutral Loss 189ES+
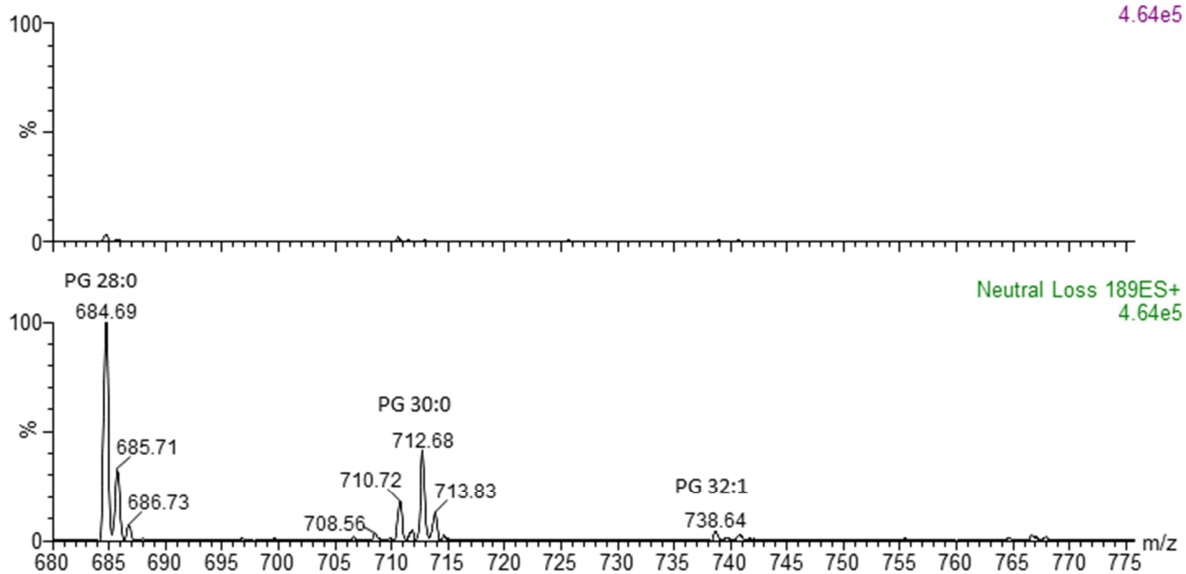